\title{
COMPARISON OF FARFAN MODIFIED AND FROBIN METHODS TO EVALUATE THE INTERVERTEBRAL DISC HEIGHT
}

\author{
COMPARAÇÃO DOS MÉTODOS DE FARFAN MODIFICADO E DE FROBIN, PARA AFERIÇÃO \\ DA ALTURA DO DISCO INTERVERTEBRAL
}

\author{
COMPARACIÓN DE LOS MÉTODOS DE FARFAN MODIFICADO E DE FROBIN PARA LA \\ MEDICIÓN DE LA ALTURA DEL DISCO INTERVERTEBRAL
}

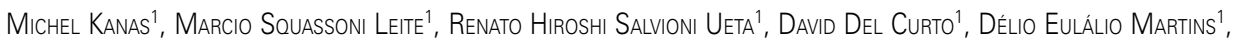

Marcelo Wajchenberg ${ }^{1}$, Eduardo Barros Puertas ${ }^{1}$

\begin{abstract}
Objective: To evaluate the reliability and reproducibility of Farfan modified and Frobin methods to measure the intervertebral disc height in radiographs with inter- and intraobserver comparison. Method: Six radiographs of different patients treated for low back pain have been collected and digitized, and five lumbar disc of each patient were evaluated by six examiners with different levels of experience. The measures were done in Image Pro Plus 6.0 software. Results: When compared, both methods showed more than 95\% concordance. In intraexaminer analysis, both also shown to be reliable and reproducible, with a high level of concordance. By comparing the correlation between classes of examiners, the higher the level of experience, the greater the agreement for both methods. Conclusion: Farfan modified and Frobin are reliable methods to measure the disc height in the lateral radiographs. The higher level of experience of the examiner, the higher was the correlation between measurements.
\end{abstract}

Keywords: Intervertebral disc; Intervertebral disc degeneration; Spinal osteochondrosis.

\begin{abstract}
RESUMO
Objetivo: Avaliar a confiabilidade e reprodutibilidade dos métodos de Farfan modificado e de Frobin, para aferição da altura radiográfica dos discos intervertebrais lombares, em comparação inter e intraobservadores. Método: Foram coletadas e digitalizadas imagens radiográficas de seis pacientes em acompanhamento ambulatorial por lombalgia, sendo avaliados cinco discos lombares de cada paciente. As mensurações foram realizadas no software Image Pro Plus versão 6.0, por seis examinadores com diferentes níveis de experiência. Resultados: Ao serem comparados entre si, os métodos demonstraram concordância superior a 95\%. Na análise intraexaminadores, ambos também demonstraram ser reprodutíveis e confiáveis com alta concordância. Ao comparar a concordância entre as classes dos examinadores, quanto maior o nível de experiência maior foi a concordância em ambos os métodos. Conclusão: Tanto o método de Farfan modificado quanto o de Frobin, podem ser utilizados de forma confiável para avaliar a altura discal nas radiografias em perfil. Quanto maior o nível de experiência do examinador, mais alta foi a concordância entre as aferições.
\end{abstract}

Descritores: Disco intervertebral; Degeneração do disco intervertebral; Osteocondrose da coluna vertebral.

\section{RESUMEN}

Objetivo: Evaluar la confiabilidad y reproducibilidad de los métodos de Farfan modificado y Frobin para medición de la altura radiográfica de los discos intervertebrales lumbares por comparación inter e intraobservadores. Método: Imágenes radiográficas fueron recogidas y digitalizadas de 6 pacientes con queja de dolor lumbar; fueron evaluados cinco discos lumbares de cada paciente. Las mediciones fueron realizadas en el software Image Pro Plus versión 6.0, por seis examinadores con diferentes niveles de experiencia. Resultados: Al ser comparados entre sí, los métodos demostraron concordancia superior a 95\%. En el análisis intraexaminador, ambos métodos también se demostraron reproductibles y confiables con alta concordancia. Al comparar la concordancia entre las clases de los examinadores, cuanto mayor el nivel de experiencia mayor fue la concordancia entre ambos métodos. Conclusión: Tanto el método de Farfan modificado como el de Frobin, pueden ser utilizados de forma confiable para evaluar la altura discal en las radiografías en perfil. Cuanto mayor el nivel de experiencia del examinador, mayor la concordancia entre ambas mediciones.

Descriptores: Disco Intervertebral; Degeneración del disco intervertebral; Osteocondrosis de la columna vertebral.

\section{INTRODUCTION}

Degenerative disc disease is considered to be a major factor in low back pain. Clinical and experimental studies have linked chronic low back pain with intervertebral disc disease in up to $40 \%$ of cases. Discogenic pain can be divided into subgroups, such as herniation, disc degeneration or disruption, ${ }^{1,2}$ those that generate functional and work disabilities, having a large socioeconomic impact. ${ }^{3}$

Kirkaldy-Willis and Farfan classified the degenerative process into
3 phases: the first, called dysfunction, is found in individuals with 15 to 45 years and is characterized by small tears in the annulus fibrosus and the presence of synovitis in the facet joints. In the following phase, the instability, individuals with 35 to 70 years present with internal disc disruption, progressive disc resorption, degeneration of the articular facets with capsular laxity and subluxation. The last phase, the stabilization, occurs around age 60, when osteophyte development around the disc and the facet joints causes segmental stiffness or true ankylosis. ${ }^{4}$

1. Department of Orthopedics andTraumatology, Escola Paulista de Medicina da Universidade Federal de São Paulo (Unifesp), São Paulo, SP, Brazil.

Study conducted at the Department of Orthopedics and Traumatology, Escola Paulista de Medicina da Universidade Federal de São Paulo (Unifesp), São Paulo, SP, Brazil. Correspondence: Al. Joaquim Eugênio de Lima 1656, ap.141, Jardim Paulista, São Paulo, SP. Brasil. 01403-002 - michelkanas@ hotmail.com 
Loss of disc height in the lateral radiographs of the spine, osteophyte formation, Schmorl's node, end plate sclerosis and vacuum sign have been described as signs of late disc degeneration. ${ }^{5}$ Intervertebral osteochondrosis is the term used when these radiographic findings are seen together. ${ }^{3,6}$

There are several radiographic methods for measuring intervertebral disc height on profile radiographs, such as the Hurxthal method 1 and 2 and the Farfan method. ${ }^{7}$ A modification of the latter showed high reliability. (Figure 1) Based on the fact that a non-ideal radiographic angulation could alter the correct measurement of disc height, in their 1997 study, Frobin et al. ${ }^{7}$ developed a technique that seeks to correct this possible error by calculating the bisection of the midlines of the adjacent vertebrae. ${ }^{7-9}$ (Figure 2)

The aim of the study was to measure the radiographic height of lumbar intervertebral discs by means of the modified Farfan method and the Frobin method, making inter- and intraobserver comparisons.

\section{MATERIAL AND METHOD}

After review and approval of the study by the Research Ethics Committee, radiographic examinations of the patients were selected according to the following criteria: minimum age of 18 years; either sex; history of low back pain already in monitoring and investigation of the comorbidity outpatiently; having performed magnetic resonance imaging (MRI) of the lumbosacral spine; and having signed an informed consent form.

The following were used as exclusion criteria: patients with previous surgical treatment of the spine; radiographic congenital abnormalities such as vertebral malformations; scoliosis greater than 15 degrees; presence of listhesis with more than $20 \%$ slip; tumor diseases.

The images were collected from outpatients and measurements were performed later in Image-Pro ${ }^{\circledR}$ Plus version 6.0 software, based on the modified Farfan method and the Frobin method. (Figures 1A-D, 2, 3 and 4)

Two residents in spine surgery, two surgeons with up to 5 years experience (intermediate) and two surgeons with over 5 years experience (senior) calculated the disc height according to the modified Farfan method and the Frobin method, as described in Figures 1A-D and $2{ }^{7}$ The unit of measurement adopted was the pixel. After a period of three months, a new measurement of the same sample (six patients, 30 discs) was requested in order to identify possible inter- and intraobserver differences.

The results were analyzed using the intraclass correlation coefficient (ICC). Analysis of concordance was performed between methods, among all examiners according to experience, among all examiners and intraexaminer, with their respective 95\% confidence intervals. ${ }^{10}$

The ICC is a parametric method to evaluate concordance, ranging from 0 to 1 ; the closer to 1 , the greater the agreement.

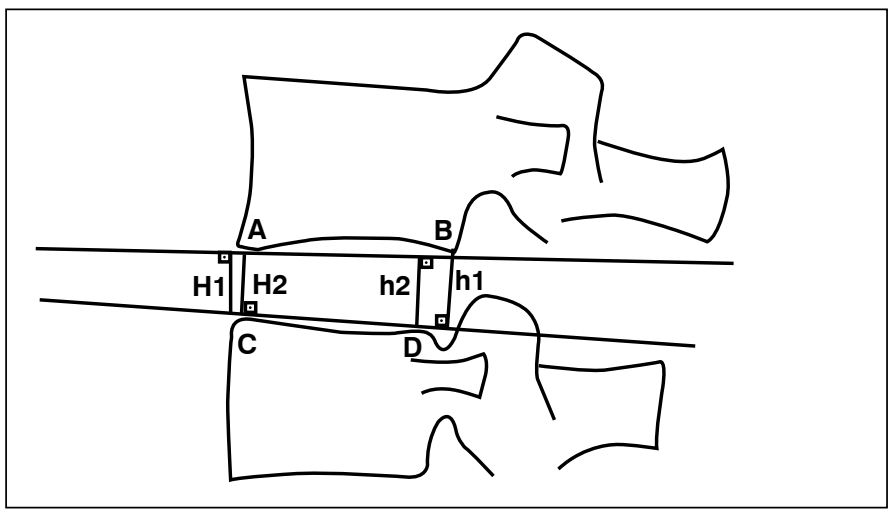

Figure 1. Measurement of the intervertebral disc height according to the modified Farfan method. Disc height $=\left(\mathrm{H}_{1}+\mathrm{H}_{2}+\mathrm{h} 1+\mathrm{h} 2\right) / 4$. (A): anteroinferior corner of the superior vertebra, (B): posteroinferior corner of the superior vertebra; $(\mathrm{C})$ : anterosuperior corner of the inferior vertebra, (D): posterosuperior corner of the inferior vertebra.
The absolute differences using mean and standard deviation were described to measure the difference between the examiners according to experience in the same method.

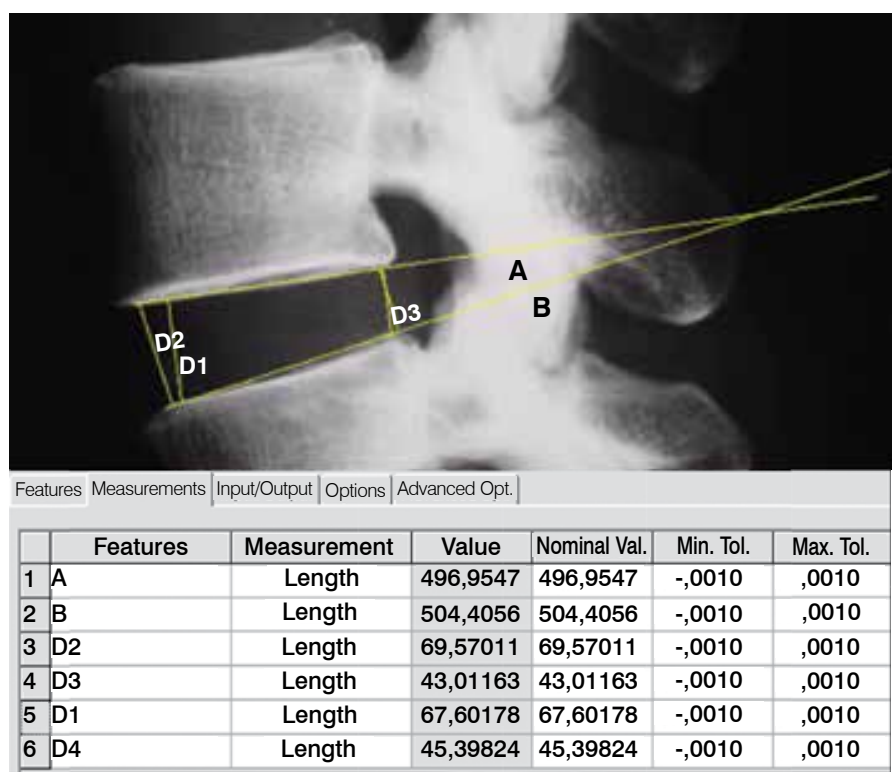

Figure 2. Image from the Image-Pro ${ }^{\circledR}$ Plus version 6.0 software demonstrating the measurement of the height of the intervertebral disc by the modified Farfan method.

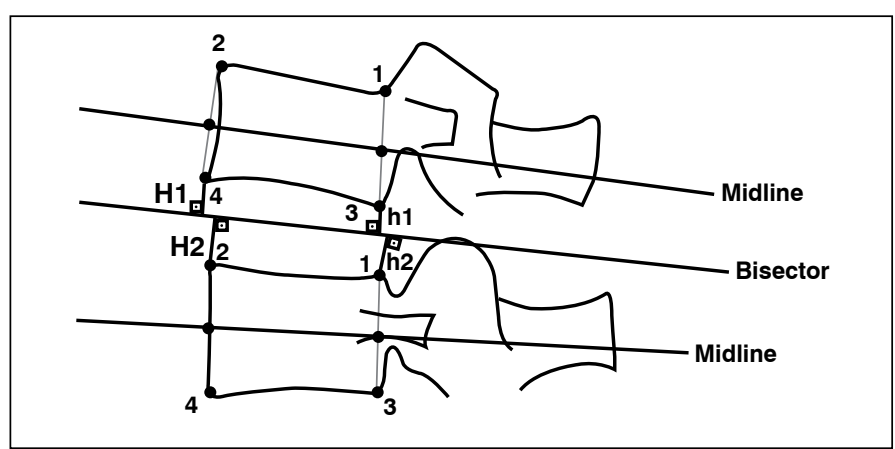

Figure 3. Measurement of the intervertebral disc height according to the Frobin method. The four corners of the vertebra are identified in the lateral radiographs $(1,2,3,4)$. The medial points, medial planes (midline) and the respective bisector are marked. Disc height is determined by the perpendicular distance between points 1 and 3 (dorsal height) and points 2 and 4 (ventral height). Disc height $=(\mathrm{H} 1+\mathrm{H} 2+\mathrm{h} 1+\mathrm{h} 2) / 2$.

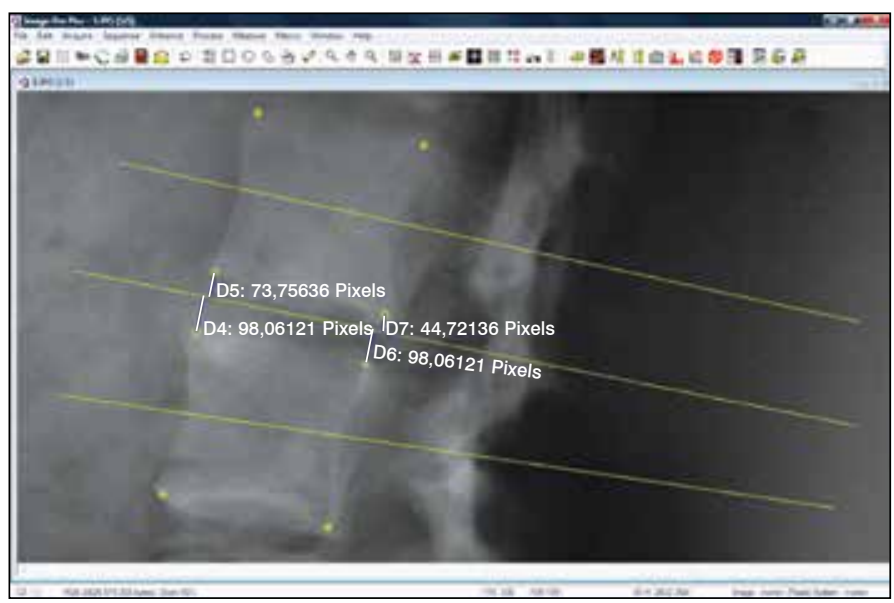

Figure 4. Image from the Image-Pro ${ }^{\circledR}$ Plus version 6.0 software demonstrating the measurement of the height of the intervertebral disc by the Frobin method. 


\section{RESULTS}

Upon comparing the agreement between the methods for each examiner, both appear to be similar and reproducible. (Table 1) When intraexaminer analysis was performed, both the modified Farfan method and the Frobin method demonstrated a high intraclass correlation coefficient (ICC), showing that they are effective. (Table 2)

When comparing the agreement between the examiners' level, the higher the experience level, the higher was the agreement in both methods. (Table 3)

Table 1. Agreement between the two methods, evaluated on the first measurement of each examiner.

\begin{tabular}{c|c|c|c}
\hline \multirow{2}{*}{ Examiner } & \multirow{2}{*}{ ICC } & \multicolumn{2}{|c}{ Cl (95\%) } \\
\cline { 3 - 4 } & & Inferior & Superior \\
\hline Senior 1 & 0.987 & 0.973 & 0.994 \\
\hline Senior 2 & 0.997 & 0.994 & 0.999 \\
\hline Intermediate 1 & 0.997 & 0.993 & 0.998 \\
\hline Intermediate 2 & 0.996 & 0.990 & 0.998 \\
\hline Resident 1 & 0.991 & 0.982 & 0.996 \\
\hline Resident 2 & 0.973 & 0.944 & 0.987 \\
\hline
\end{tabular}

Table 2. Comparisons between the first and the second measurements of the examiners for each method (Farfan 1 X Farfan 2, Frobin 1 X Frobin 2).

\begin{tabular}{c|c|c|c|c}
\hline \multirow{2}{*}{ Examiner } & \multirow{2}{*}{ Method } & \multirow{2}{*}{ ICC } & \multicolumn{2}{|c}{ Cl (95\%) } \\
\cline { 4 - 5 } & & & Inferior & Superior \\
\hline \multirow{2}{*}{ Senior 1 } & FARFAN & 0.968 & 0.934 & 0.984 \\
\cline { 4 - 5 } & FROBIN & 0.964 & 0.918 & 0.983 \\
\hline \multirow{2}{*}{ Senior 2 } & FARFAN & 0.969 & 0.916 & 0.987 \\
\cline { 2 - 5 } & FROBIN & 0.962 & 0.882 & 0.985 \\
\hline \multirow{3}{*}{ Intermediate 1 } & FARFAN & 0.969 & 0.936 & 0.985 \\
\cline { 2 - 5 } Intermediate 2 & FROBIN & 0.974 & 0.946 & 0.987 \\
\hline \multirow{2}{*}{ Resident 1 } & FARFAN & 0.980 & 0.959 & 0.991 \\
\cline { 2 - 5 } & FROBIN & 0.978 & 0.953 & 0.989 \\
\hline & FARFAN & 0.964 & 0.925 & 0.983 \\
\cline { 2 - 5 } & FROBIN & 0.968 & 0.894 & 0.987 \\
\hline \multirow{2}{*}{ Resident 2 } & FARFAN & 0.885 & 0.774 & 0.943 \\
\cline { 2 - 5 } & FROBIN & 0.898 & 0.798 & 0.950 \\
\hline
\end{tabular}

\section{DISCUSSION}

Several factors determine the complex pathophysiology of disc degeneration, which remains poorly understood. ${ }^{3}$ The normal intervertebral disc presents anatomical and biochemical characteristics that allow it to absorb and dissipate the loads transmitted between the segments of the spine..$^{3,11}$ It is composed of three structures: the annulus fibrosus, the nucleus pulposus, and the endplate. The annulus fibrosus is highly organized in 15 to 40 lamellae made of collagen fibers positioned between themselves at a $30^{\circ}$ angle. ${ }^{12}$ The endplate is composed of hyaline cartilage, which covers the upper and lower surface of the vertebral body, and serves as a biomechanical and metabolic interface with the nucleus pulposus. The nucleus pulposus is composed of delicate networks of well hydrated fibers, with the residual material of the notochord, forming a gelatinous matrix. Type II collagen, proteoglycans, and glycosaminoglycans comprise $10-15 \%$ of the healthy nucleus pulposus. ${ }^{3}$ Along with $85-$ $90 \%$ water, they allow the intervertebral disc to perform its function.

Disc degeneration starts around the third decade of life, with dehydration of the nucleus pulposus and changes in the molecular structures of their components. ${ }^{13}$ Thus, there is an increase in the formation of type I collagen and an increase in type II collagen, reducing the content of the latter and the amount of aggrecan in the nucleus pulposus, ${ }^{14}$ which affects its ability to retain water and modifies its hydrostatic properties.

In their study comparing changes on radiographies and magnetic resonance imaging of patients with potential degenerative disc disease related to work involving weight lifting, Frobin et al. ${ }^{8}$ concluded that the loss of disc height is a late finding in degenerative disc disease, being preceded by the loss of the normal disc signal on MRI, disc prolapse and signal changes in adjacent vertebral endplates. They also observed that postural changes, such as decreased lumbar lordosis, can alter the measurement of disc height, as well as the biotype of the patient, so the assertion that there is a decrease in disc height at a certain level should only be made after a comparison with the patient's other lumbar discs.

In contrast to the classic findings in the literature, when using the protocol for measurement of disc height described by Frobin et al., ${ }^{8}$ we concluded that the disc height increases with age until the seventh decade, a fact explained by the increased concavity of the vertebral endplates with age. After the seventh decade, decreased disc height was justified by the loss of material due to disc herniation or the loss of volume due to dehydration. ${ }^{9}$

It was also shown that the disc height can vary according to time of day, age, and activity performed. In the morning, the disc height tends to be higher than at the end of the day. After performing physical activity with axial loads, the disc height decreases more in the young than in the elderly, since in the latter the disc is more dehydrated and hardened. ${ }^{15}$

In our study, both methods have proved to be reliable and reproducible, with the modified Farfan method showing a slight advantage. Moreover, due to the method having a simpler technique, it was also preferred by the examiners.

The fact that the comparison of the first with the second measurement of each method (Farfan 1 x Farfan 2 and Frobin 1 x Frobin 2)

Table 3. Agreement between the different experience levels considering the first measurement for both methods.

\begin{tabular}{|c|c|c|c|c|c|c|c|c|c|c|}
\hline \multirow{2}{*}{ Examiner } & \multicolumn{3}{|c|}{ FARFAN } & \multirow{2}{*}{$\begin{array}{c}\begin{array}{c}\text { Absolute } \\
\text { difference }\end{array} \\
\text { Mean }\end{array}$} & \multirow{2}{*}{ ICC SD } & \multicolumn{3}{|c|}{ FROBIN } & \multirow{2}{*}{\multicolumn{2}{|c|}{ Absolute difference }} \\
\hline & ICC & \multicolumn{2}{|c|}{$\mathrm{Cl}(95 \%)$} & & & \multicolumn{2}{|c|}{$\mathrm{Cl}(95 \%)$} & Superior & & \\
\hline Seniors & 0.973 & 0.941 & 0.987 & 6.61 & 5.38 & 0.967 & 0.925 & 0.985 & 7.32 & 5.82 \\
\hline Intermediates & 0.923 & 0.846 & 0.962 & 8.24 & 10.01 & 0.926 & 0.851 & 0.964 & 8.62 & 9.64 \\
\hline All & 0.887 & 0.784 & 0.944 & & & 0.883 & 0.768 & 0.942 & & \\
\hline
\end{tabular}


presented lower agreement than the comparison between the methods in the first measurement (Farfan $1 \times$ Frobin 1) drew our attention. This fact can be explained by the degree of similarity between the methods and by Farfan 1 and Frobin 1 being measured at the same time.

\section{CONCLUSION}

Both methods proved to be reliable and reproducible for the measurement of disc height.
The higher the level of experience of the examiner, the higher the agreement in the measurements, demonstrating that more experienced surgeons may be more cautious and accurate at the time of measuring the disc height.

All authors declare no potential conflict of interest concerning this article.

\section{REFERENCES}

1. Schwarzer AC, Aprill CN, Derby R, Fortin J, Kine G, Bogduk N. The prevalence and clinical features of internal disc disruption in patients with chronic low back pain. Spine (Phila Pa 1976). 1995;20(17):1878-83.

2. Manchikanti L, Singh V, Pampati V, Damron KS, Barnhill RC, Beyer C et al. Evaluation of the relative contributions of various structures in chronic low back pain. Pain Physician. 2001;4(4):308-16.

3. Modic M, Masaryk T, Ross J, Carter J. Imaging of degenerative disk disease. Radiology. 1988;168(1):177-86.

4. Kirkaldy-Willis WH, Farfan HF. Instability of the lumbar spine. Clin Orthop Relat Res. 1982:(165):110-23,

5. Madan SS, Rai A, Harley JM. Interobserver error in interpretation of the radiographs for degeneration of the lumbar spine. lowa Orthop J. 2003;23:51-6.

6. Modic MT, Steinberg PM, Ross JS, Masaryk TJ, Carter JR. Degenerative disk disease: assessment of changes in vertebral body marrow with MR imaging. Radiology. 1988;166(1 Pt 1):193-9

7. Frobin $\mathrm{W}$, Brinckmann P, Biggemann M, Tillotson M, Burton K. Precision measurement of disc height, vertebral height and sagittal plane displacement from lateral radiographic views of the lumbar spine. Clin Biomech (Bristol, Avon). 1997;12(Suppl 1):S1-63.

8. Frobin W, Brinckmann P, Kramer M, Hartwig E. Height of lumbar discs measured from

radiographs compared with degeneration and height classified from MR images. Eur Radiol. 2001;11(2):263-9.

9. Shao Z, Rompe G, Schiltenwolf M. Radiographic changes in the lumbar intervertebral discs and lumbar vertebrae with age. Spine (Phila Pa 1976), 2002;27(3):263-8.

10. Fleiss JL. The design and analysis of clinical experiments. New York: Wiley; 1986

11. Biyani A, Haman SP, Andersson GB. Lumbar disc desease. In: Herkowitz HN, Garfin SR, Eismont FJ, editors. Rothman-Simeone the spine. 5th ed. Philadelphia: Saunders Elsevier 2006. p. 930-44.

12. Wang C, Auerbach JD, Witschey WR, Balderston RA, Reddy R, Borthakur A. Advances in Magnetic Resonance Imaging for the assessment of degenerative disc disease of the lumbar spine. Semin Spine Surg. 2007:19(2):65-71.

13. Nguyen AM, Johannessen W, Yoder JH, Wheaton AJ, Vresilovic EJ, Borthakur A, et al. Noninvasive quantification of human nucleus pulposus pressure with use of T1rhoweighted magnetic resonance imaging. J Bone Joint Surg Am. 2008;90(4):796-802.

14. Gruber HE, Hanley EM Jr. Analysis of aging and degeneration of the human intervertebral disc. Comparison of surgical specimens with normal controls. Spine (Phila Pa 1976) 1998;23(7):751-7.

15. Adams MA, Dolan P, Hutton WC, Porter RW. Diurnal changes in spinal mechanics and their clinical significance. J Bone Joint Surg Br. 1990;72(2):266-70. 